\title{
Community involvement and sustainability of tourism: a discussion through local community understanding in the Eastern Black Sea Region
}

\author{
S. Kaplan \\ Department of City and Regional Planning, \\ Istanbul Technical University, Turkey
}

\begin{abstract}
Turkey is one of the developing countries which aims to increase its national share of tourism revenue. Therefore the Turkish Republic Ministry of Culture and Tourism published its Turkey Tourism 2023 Strategy Action Plan in order to spotlight regional tourism development schemes. The Eastern Black Sea Region is one of the regions in which sustainable niche tourism activities is highlighted to be implemented. This study aims to understand "How far the local residents in the Eastern Black Sea Region embrace tourism activities taking place in their local environment?" In order to answer this question explicitly, the theoretical part must be set forth first in order to understand the connections between sustainable development and community involvement. Second, a perception study will be used to realize how the community evaluates tourism development in their region in respect to social, economic and environmental dimensions. Finally, the residents' attitudes towards tourism development will be linked to their involvement in the tourism development process. A questionnaire was designed in light of the sustainability indicators, including Sustainable Tourism Attitude Scale (SUSTAS) indicators. 100 people were covered in the questionnaire. Descriptive statistics, factor analysis, frequencies of statements and correlations between statements were tested. Results show that; residents' attitudes towards community participation positively associated with negative impacts of tourism development. Exemption of local residents from the tourism planning and decision making process indicates the ignorance of one of the main principles of sustainable tourism development.

Keywords: sustainable tourism development, community participation, perception study.
\end{abstract}




\section{Introduction}

Tourism is recognized as one of the leading sectors in the world's economy. As it is indicated by The United Nations World Tourism Organization (UNWTO) [1], tourism is one of the largest and fastest growing economic sector. New destinations in the world get introduced to receive more share from tourism benefits.

Turkey wants to increase its national share from international tourism revenues. Therefore, many new destinations get introduced for various tourism development schemes. The Eastern Black Sea Region is one containing ecotourism facilities.

This research aims to understand "How far the local residents in the Eastern Black Sea Region embrace tourism activities taking place in their local environment?" To answer this question sustainable tourism, community tourism and sustainable tourism assessment methods are explained. The research methodology is also given.

\section{Sustainable tourism}

The tourism industry has many positive effects on local communities' development. As it is asserted by Lankford and Howard [2] “... tourism is a source of new employment, revenues, additional tax receipts, foreign exchange benefits, and enhances community infrastructure that will, in turn, attract other industries". In contrast to positive effects on local development, tourism has negative effects like: environmental degradation; natural resource depletion; dependence on foreign capital; loss of cultural identity; unfair distribution of wealth; and creation of conflict between residents.

Conventional mass tourism, which is the most common type of tourism in the world, is widely accepted as an unsustainable form of tourism because it omits sustainable development principles and objectives. Therefore, as Hunter [3] states, the paradigm of conventional tourism development has widely shifted to sustainable tourism development.

As the WTO [4] indicates "sustainable tourism development meets the needs of present tourists and host regions while protecting and enhancing opportunities for the future. It is envisaged as leading to management of all resources in such a way that economic, social and aesthetic needs can be fulfilled, while maintaining cultural integrity, essential ecological processes, biological diversity and life support systems". There are three main pillars of sustainable tourism referred to by Cater [5] as; "meeting the needs of the host population in terms of improved living standards both in the short and long term; satisfying the demands of a growing number of tourists; and safeguarding the natural environment in order to achieve both of the preceding aims".

Integration of local communities to the planning and management process of tourism development is crucial to reach sustainability of tourism. Moreover, according to Telfer and Sharpley [6] "the principle of community involvement appears to satisfy the specific requirements of self-reliance and endogenous development that are critical elements of sustainable development paradigm". 
The concerns related to host communities integration into tourism development process leads to the emergence of a new concept called sustainable community tourism (SCT). According to Gunn [7], SCT refers to a type of tourism that does not damage social, environmental and cultural systems of the community.

\subsection{Community based tourism}

Community based tourism (CBT) indicates a type of tourism providing high levels of community participation under the sustainability umbrella. In community based tourism, the community's well-being is an important criterion and tourism development should enable maximum benefit to local people in reference to sustainability principles. To maintain CBT, active participation of community residents is indispensable.

It is accepted by some researchers that participatory planning process is time consuming and ineffective because of lack of local knowledge and collaboration. However, Boothroyd [8] asserts participatory planning is more likely to achieve sustainable tourism development by ensuring more equitable decisions via local knowledge. Moreover, participatory planning process enables the building up of self-sufficient societies, by which protection of cultural and natural resources can be achieved.

Most of the case studies show local residents are exempted from the tourism development process and it makes the community resentful of tourism and tourists [9]. Thus, tourism development becomes unsustainable because an important sustainable tourism principle is omitted. According to Choi and Sirakaya [10], local residents should take part in the decision making process if political, social, economic, cultural and environmental sustainability wants to be achieved.

\subsection{Sustainable tourism assessment}

Development refers to an improvement in human condition. As development considers human well-being, sustainable tourism development should maintain a state of health within the condition of acceptable and desirable standard for survival of a living system which can either be an ecosystem or a human system [11]. Unfortunately, in today's world, tourism has been developing in an inorganic way damaging human systems and ecosystems. Exemption of local communities from tourism decision making processes conduces to such development schemes. According to Choi and Murray [12], lots of studies show that participation of the local community in the tourism planning process is short-lived, passive, partial, static and minimal. However, in a sustainability context a high level of community participation is important in order to realize the basic needs and expectations of community about their living environment. According to Inskeep [13], "this is based on the concept that planning is for the residents of an area, and they should be given the opportunity to participate in the planning of its future development and express their views on the type of future community they want to live in".

Although many researchers agree that tourism should be sustainable, there are few examples of its applications. According to Bramwell and Lane [14], 
sustainable tourism development arguments are mostly on the theoretical level rather than practical level.

The measurement methods of sustainable tourism are still blurry in terms of its qualitative and quantitative indicators. According to Ko [11], most of the academics try to measure sustainability of tourism without giving proper reference or any standardized criteria. Therefore, beginning from the 1990s, impact assessment studies have gained importance while it has been agreed upon that there is a strong correlation between sustainability of tourism and perception of community. According to Bell and Morse [15], community gives relatively clear information about existing tourism development in respect to sustainability. According to Choi and Sirakaya [10], the local community's role in tourism development is important because they build "the philosophical basis of sustainable community tourism (SCT)". Therefore Choi and Sirakaya [10] asserted "each community should adopt only the indicators it needs to monitor tourism development".

Sustainable tourism indicators basically focused on economic, ecological and physical dimensions. However, it should also be composed of social, cultural, technological and political dimensions [10]. As Choi and Sirakaya [10] indicated; "a holistic approach to sustainable tourism development should be ecologically responsible, socially compatible, culturally appropriate, politically equitable, technologically supportive and, finally, economically viable for the host community". For this reason, Choi and Sirakaya [10] defined six dimensions of sustainable tourism so as to construct Sustainable Tourism Attitude Scale (SUSTAS) which are: economic benefits; the sociocultural impact of tourism; community-based benefits; visitor satisfaction; environmental sustainability; and community participation.

\subsection{Sustainable Tourism Attitude Scale (SUSTAS)}

SUSTAS was constructed by Choi and Sirakaya [10] in order to create a reliable and applicable sustainability assessment method for tourism development. At the initial phase of SUSTAS, 44 researchers were selected to define sustainability indicators for tourism. After three rounds of discussion from panel members, 125 sustainability indicators were received. The received sustainability indicators were tested by conducting a pilot survey with 308 people from a university in Texas. The sample size satisfied the condition of a minimum of 300 people for exploratory factor analysis. Kaiser-Meyer-Olkin also used to test sample size.

The sustainability indicators, with low or no correlation ( $\mathrm{r}$ value less than .3), were discarded and an exploratory factor analysis was performed on the remaining 53 sustainability and 38 of them loaded on seven dimensions. To test consistency reliability, Cronbach alpha is used and the variables with the score above 0.6 accepted as reliable. In Choi and Sirakaya's [10] work, Cronbach alpha coefficients ranged from 0.64 to 0.89 that indicates the variables were consistent. The final instrument of SUSTAS included 51 indicators with seven domains. The reliability of SUSTAS indicators were tested by conducting 447 questionnaires in New Braunfels, Texas. Principal Component Analysis with varimax rotation used to interpret the factors and 44 items remained. Cronbach alpha is also used to test 
the internal consistency and coefficients ranged from 0.79 to 0.95 . Thus, internal consistency of the SUSTAS is highly acceptable.

According to Choi and Sirakaya [10], the psychometric characteristics of SUSTAS should be verified in order to understand whether it can be used in crosscultural and urban settings. Therefore, Sirakaya et al. [16] studied to refine the scale of SUSTAS with a new sample. Sirakaya, et al. [16] studied two samples chosen from Turkey and The Turkish Republic of Northern Cyprus to confirm the validity of SUSTAS. Confirmatory factor analysis was used to test the validity of SUSTAS. Seven factor dimensions of SUSTAS were confirmed with 33 items. The reliability of SUSTAS was confirmed and the findings approved that SUSTAS can be used in cross-cultural settings.

\section{Research design}

The research was designed around testing local residents' perception about tourism development. As UNEP/WTO [17] indicated, local satisfaction and perception are the main issues of sustainable tourism development. In this research, most of the sustainable tourism indicators were adapted from SUSTAS. As Sirakaya et al. [16] pointed out; the validity and reliability of SUSTAS in cross-cultural settings is highly acceptable. The sustainability indicators included in the survey mostly related with; community participation, perceived economic benefits, environmental sustainability, perceived social costs and long-term planning.

\subsection{Research question and the research hypotheses}

As Choi and Murray [12] asserted "Within the sustainability paradigm, the role of residents is crucial and it is important to understand and assess their perceptions of, and attitudes toward, development". Therefore the key research question was set forth as: "How far the local residents in the Eastern Black Sea Region embrace tourism activities taking place in their local environment?"

Planning activity and community involvement in the decision making process are the key elements of sustainable tourism development. According to Napier and Wright [18], there is a strong correlation between positive perceptions of tourism and the degree of participation. Therefore; the hypothesis was set forth as: residents' attitudes towards community participation are positively associated with negative impacts of tourism development.

\subsection{The questionnaire}

The questionnaire includes ten questions and descriptive information. Descriptive information consists of; residents' age, gender, length of residency, education level, relation with tourism sector and income level. In the questionnaire; Yes/No questions and Likert scale anchored questions are included. The Likert scale anchored questions are structured as: $1=$ strongly disagree and $5=$ strongly agree to be used for rating. 
Residents were questioned on whether tourism is an important sector for their regions' development. They were also asked whether they get quantifiable personal benefit from existing tourism activities. As Perdue et al. [19] state, there is a positive correlation between personal benefits and tourism support. Perceived negative and positive effects of existing tourism were also investigated. Respondents were asked whether tourism has more negative effects than positive effects in their region. Specifically, the ecological dimension of tourism was researched in correspondence to its negative effects. Therefore, respondents were questioned whether they agree with the statement of: "The Eastern Black Sea region will no longer be an attractive tourism destination for tourist, if the natural environment is not protected". Community participation is the core principle of sustainable tourism development. For this reason, residents were deeply questioned about participation, attitudes of local/central governments towards their involvement in tourism planning, their tendency to participate in decision making process and their readiness to collaborate with public bodies. The Likert scale anchored question includes sustainability criteria of SUSTAS. It consists of; social, political, economic and ecological dimensions of sustainability.

\subsection{Research area and sample selection}

The Eastern Black Sea Region is one of the most important regions in Turkey in relation to its natural beauty and nature based tourism development opportunities. In national tourism development plans, the region was emphasized as a 'Plateau Corridor' attracting various tourist profiles. Beginning in the 2000 s, various tourism investments and activities have been taking place in the Eastern Black Sea Region. However, the Eastern Black Sea Region faces various problems regarding tourism development. Seasonal fluctuations are the most important problem in the Eastern Black Sea Region. Fluctuation in tourist arrivals results in inadequate and unqualified tourism service supply causing; lack of accommodation, lack of qualified personnel, instability in tourism occupation rates, insufficient waste management, a high degree of environmental pollution and instability in economic benefits.

The questionnaire was conducted in Trabzon, which is accepted as the regional center of the Eastern Black Sea Region. Trabzon city center and Uzungöl, which is the best known touristic area of the Eastern Black Sea Region, were decided on as research sites. Both of the research areas strongly reflect the current tourism development scheme in the Eastern Black Sea Region. Trabzon is the only city in the Eastern Black Sea Region which has an airport. As it is referred to in the Eastern Black Sea Tourism Master Plan [20], almost 1/3 of tourists are coming to the Eastern Black Sea Region by airways, which means at least $1 / 3$ of tourists are directly coming to Trabzon. Therefore, it can be admitted that the research area reflects the tourism potential of the Eastern Black Sea Region in general.

The target group of the research was the local residents of Trabzon city center and Uzungöl. The sample was randomly selected and a total number of 100 surveys were conducted by face to face dialoguing; 48 of them from Trabzon city center and 52 of them from Uzungöl. 


\subsection{Research results}

According to the research results; $66 \%$ of the respondents were male and $34 \%$ of them were female. Most of them were 18-29 years old (48\%) and 75\% of them resided for more than 15 years in the research area. $42 \%$ of the respondents had a university level education, while $21 \%$ had just primary education. $63 \%$ of the respondents were working in the tourism sector and the majority had an income level of 1000-2000 TL (45.5\%).

Almost all of the respondents (96\%) thought tourism was an important sector for their region and $71 \%$ of them thought that they got a quantifiable personal benefit from tourism development. Nearly all of the respondents did not feel disturbed either by tourist or tourism development. Respondents believed tourism had various advantageous: $29 \%$ of them thought that tourism contributed to the local economy, promoted their region, increased job opportunities, improved infrastructure and developed transportation facilities. On the other side, $6 \%$ of the respondents thought that tourism damaged environmental assets, caused overcrowding and resulted in a more expensive life in their region. However, $49 \%$ of the respondents considered tourism not to have any negative effect on their region. Similarly, more than half $(57 \%)$ of the respondents disagreed that tourism destroys the natural environment. But, it was agreed upon by $49 \%$ of the respondents that the most important factor behind the deterioration of the natural environment were the wrong policies being applied by local/central authorities. Likewise, $49 \%$ of the respondents thought that local/central authorities did not take adequate precautions to protect the natural environment and that tourism developed in an unplanned way. Concerning the local economy, existing tourism development was perceived positively. $81 \%$ of respondents thought tourism made an important contribution to the local economy and $79 \%$ of them thought tourism diversified the local market. $83 \%$ of the respondents liked tourism because they believed that tourism brought new income to their community. Similarly, $77 \%$ of the respondents agreed tourism created new markets for their local products.

More than half of the respondents (54\%) believed that local/central authorities did not give the right to local citizens to participate in tourism decision making and $84 \%$ of them thought that the community should be given an opportunity to get involved in the tourism decision making process. Similar to this, $45 \%$ of the respondents expressed it was hard for them to make contact with the related authority when they had problems concerning tourism. It was believed by $59 \%$ of the respondents that one of the most important obstacles of a planned tourism development in their region lies behind their disqualification from the tourism planning process.

Factor analyses were only applied to the Likert scale anchored 20 statements. The principal component method with the Varimax rotation was used to assess the psychometric properties of each item. Factors with eigenvalues greater than one and a factor loading of 0.7 or above were chosen for interpretation. The principal component method revealed a structure of 9 components which explain $73 \%$ of the total variance. Factor analyses and item scores shows that; wrong policies 
applied by the local authorities cause important deterioration in the natural environment of the region. Residents think they do not get given the right by local administrations to be involved in the decision making process. Respondents believe tourism has a great contribution to the local economy and creates new markets for their local products.

The Chi-square test and Cross-tabulation were used to test correlations between statements. The results show that; residents benefiting from tourism are less likely to think tourism deteriorates the natural environment $(\mathrm{p}=0.027)$. Respondents who think it is hard to make contact with local/central authorities when they have problems about tourism, are more likely to believe "The Eastern Black Sea region will no longer be an attractive tourism destination for tourists, if the natural environment is not protected" $(\mathrm{p}=0.045)$. Additionally, respondents thinking local administrations do not take adequate precautions to protect the natural environment, tend to think the most important factor behind deterioration of the natural environment is the wrong policies of local/central administrations and they also state local/central administrations do not give them right to participate in tourism decision making. Similarly, residents agree that their disqualification from the tourism planning process corresponds to unplanned tourism development. Moreover, residents perceive that the most important obstacles of planned tourism development in their region lies behind their disqualification from the tourism planning process. The Chi-square test shows that they should be given more opportunity to take part in the tourism decision making process. Thus, hypothesis: residents' attitudes towards community participation positively associated with negative impacts of tourism development is verified.

In economic terms, tourism is seen as an important sector for regional development. Residents believe that tourism diversifies the local economy and it brings new income to their society. For this reason, residents like tourism. Moreover, they think tourism should hire at least one-half of their employees from within community and tourism benefits should be equally distributed among all residents within the community.

\section{Discussion and conclusions}

Sustainable development has a holistic approach concerning the idea of balance between human systems and ecosystems. According to Hopwood et al. [21] "The widespread rise of interest in, and support for, the concept of sustainable development is potentially an important shift in understanding relationships of humanity with nature and between people". Unfortunately, in most of the cases, specifically in tourism development, understanding the relationships between humanity and nature is ignored. However, as Boothroyd [8] indicates; participatory planning process ensures more equitable decisions by using local knowledge so that tourism can be developed in a more sustainable manner.

In the Eastern Black Sea Region case, tourism is seen as a positive phenomenon in terms of its contribution to local economic development. However, residents believe they are exempted from tourism decision making and management process. $45 \%$ of the local residents state that it is hard for them to make contact 
with the related authority when they have problems with tourism development. This actually shows a strict top-down policy planning and implementation process in the Eastern Black Sea Region. Yet, the case should have a high level of and effective community participation so as to maintain sustainable community tourism. As Bell and Morse [15] pointed out; "local people often have clear ideas of their own about what is sustainable from their own perspective and in their own terms without an expert's view". Just as Bell and Morse [15], Choi and Sirakaya [10] also stressed out the importance of local peoples participation and asserted that local people construct the "the philosophical basis of sustainable community tourism (SCT)". [10]. For the long term sustainability of tourism, local governments and decision makers should enable residents to be involved in the tourism planning process. As Choi and Murray [12] states; "planners, developers and political leaders need to realize that the full participation of community residents does not interfere with the planning process, but enhances it". Therefore, more bottom-up policies should be applied and residents should involve.

\section{References}

[1] United Nations World Tourism Organization, Tourism Highlights 2012 Edition, UNWTO Publications, 2012.

[2] Lankford, S. V. and Howard, D. R. Developing a tourism impacts attitude scale, eds. Ko, S. and Steward, W.P., A Structural Equation Model of Residents' Attitudes for Tourism Development, Tourism Management 23, pp. 521-530, 2002.

[3] Hunter, C., Sustainable Tourism as an Adaptive Paradigm, Annals of Tourism Research 24, pp. 850-67, 1997.

[4] WTO, The concept of sustainable tourism eds. Liu, Z. Sustainable Tourism Development: A Critique Journal of Sustainable Tourism 11, pp. 459-475, 2010.

[5] Cater, E., Ecotourism in the Third World: Problems for sustainable tourism development eds. Liu, Z. Sustainable Tourism Development: A Critique Journal of Sustainable Tourism 11, pp. 459-475, 2010.

[6] Telfer, D.J and Sharpley, R., Tourism and Development in the Developing World, Routledge, New York, 2008.

[7] Gunn, C. A. Tourism Planning: Basics, Concepts, Cases (3rd eds.), Washington DC, Taylor and Frances, 1994.

[8] Boothroyd, P, Enhancing Local Planning Skills for Native Self-Reliance: The UBC Experience, The Canadian Journal of Native Studies 4(1), pp. 1342, 1986.

[9] Hall, C. M., Tourism \& politics: Policy, power, \& place, Chichester, West Sussex: John Wiley \& Son Ltd, 1994.

[10] Choi, H.C. and Sirakaya, E., Measuring Residents' Attitude toward Sustainable Tourism: Development of Sustainable Tourism Attitude Scale', Journal of Travel Research 43(4), pp. 380-394, 2005.

[11] Ko, T. G., Development of a Tourism Sustainability Assessment Procedure: a Conceptual Approach, Tourism Management 26, pp. 431-445, 2003. 
[12] Choi, H.C. and Murray, I., Residents Attitudes toward Sustainable Community Tourism, Journal of Sustainable Tourism 18(4), pp. 575-594, 2010.

[13] Inskeep, E., Tourism Planning: An Integrated and Sustainable Development Approach, Van Nostrand Reinhold, 1991.

[14] Bramwell, B. and Lane, B., Sustainable tourism: An evolving global approach, Journal of Sustainable Tourism 1(1), pp. 6-16, 1993.

[15] Bell, S. and Morse, S., Sustainability indicators: Measuring the immeasurable, London: Earthscan, eds. Ko, T.G., Development of a Tourism Sustainability Assessment Procedure: a Conceptual Approach, Tourism Management 26, pp. 431-445, 2005.

[16] Sirakaya, E., Yusel E. and Kaya A. G., An Examination of the Validity of SUS-TAS in Cross-Cultures, Journal of Travel Research 46(4), pp. 414-421, 2008.

[17] UNEP/WTO Making tourism more sustainable: a guide for policy makers, Paris/Madrid: United Nations Environment Programme/ World Tourism Organization, 2005.

[18] Napier, T.L. and Wright, C.J., Impact of rural development: Case study of forced relocation, Journal of Community Development Sociology 5, pp.107-115, 1974.

[19] Perdue, R. R., Long, P. T., and Allen, L. R., Resident support for tourism development, Annals of Tourism Research 17(4), pp. 586-599, 1990.

[20] Eastern Black Sea Tourism Master Plan, Barlas Imar Planlama Müşavirlik Ltd. Şti Ankara, 2010.

[21] Hopwood B., Mellor M. and O'Brien G., Sustainable development: mapping different approaches, Journal of Sustainable Development 13(1), pp. 38-52, 2005. 